\title{
Divalent metal ion removal from aqueous solution by acid-treated and garlic-treated Canna indica roots
}

\author{
"MAHAMADI, C; CHAPEYAMA, R \\ Chemistry Department, Bindura University of Science Education, P. Bag 1020, \\ Bindura, Zimbabwe
}

\begin{abstract}
The biosorption of different metal ions $\left(\mathrm{Cu}^{2+}, \mathrm{Zn}^{2+}, \mathrm{Ni}^{2+}, \mathrm{Pb}^{2+}\right.$ and $\left.\mathrm{Co}^{2+}\right)$ by dried roots of Canna indica biomass was investigated using a batch sorption technique. The equilibrium retention capacities of the metal ions determined from the Langmuir isotherm showed that $C$. indica had the largest sorption capacity for $\mathrm{Pb}^{2+}$ ions and the least sorption for $\mathrm{Ni}^{2+}$. The results also showed that garlic-treatment of $C$. indica biomass enhanced its sorption capacity for the divalent metal ions, with the enhancement factor varying from 1.22 to 1.44 . The biosorption process was found to be exothermic for all metal ions studied ( $\Delta H$ values varying from -4.438 to $-12.716 \mathrm{~kJ}^{\text {mol }}{ }^{-1}$ ), with physisorption being the most likely mechanism of uptake. In conclusion, studies on biosorption of heavy metals by $C$. indica are important because they may contribute in aiding the innovative removal of metal ions from contaminated industrial effluents. @JASEM
\end{abstract}

The presence of heavy metals in the environment has continued to pose a challenge because of their abundance in industrial effluents, their toxicity, and other adverse effects on water bodies (Hasan et al., 2007). Therefore it is necessary that technologies for controlling the levels of these metals in aqueous discharges are developed. Several conventional technologies have been used, which range from reverse osmosis to granular activated carbon. However, there are economic challenges faced in trying to implement these technologies in small scale industries prevalent in developing countries due to huge capital investment. Attention has therefore been focused on the search for alternative adsorbents, which are low cost, often naturally occurring in abundance, have good adsorption properties and are of low value to the inhabitants.

Biosorption is a process where metal ions or metalloid species, compounds and particulate substances are removed from solution by biological material (Diniz and Volesky, 2005). In general, the binding of heavy metals occurs through surface chemical reactions such as complexation with amino, carboxylic, hydroxyl, phenolic, ester, sulfhydryl, phosphate, etc (Wang and Chen, 2009). The biosorbent materials that have been investigated have been categorized as: algae, bacteria (e.g. Escherichia coli), fungi (e.g. Rhizopus arrhizus), yeast (e.g. Saccharomyces cerevisiae), agricultural wastes (e.g. corn core), and other polysaccharide materials industrial wastes (e.g., S. cerevisiae waste biomass from fermentation and food industry), etc (Wang and Chen, 2009; Lesmana et al., 2009). For practical application considerations, it is important to select biomass types that are either naturally abundant, such as seaweeds (Naja and Volesky, 2006; Diniz et al., 2008), Eichhornia crassipes (Mahamadi and
Nharingo, 2007; Zheng et al., 2009) and Tamarindus indica (Agarwal et al., 2006; Gupta and Babu, 2009).

Canna indica is a perennial herb that is abundantly available in many tropical environments. The plant can grow up to a height of $2 \mathrm{~m}$ and the roots develop into large tubers which are not of the edible variety. From a literature survey of peer-reviewed journals done by the authors, it is evident that no work is documented on the potential of $C$. indica as a biosorbent of heavy metal ions. The effect of chemical modification of biomaterials on their metal uptake capacities has been reported previously (Horsfall Jnr, M. and Spiff, A.I., 2005; Das et al., 2007).

This study focused on investigation of the effect of acid-treatment and garlic-treatment of the $C$. indica biomass on its uptake of $\mathrm{Pb}^{2+}, \mathrm{Ni}^{2+}, \mathrm{Cu}^{2+}, \mathrm{Zn}^{2+}$ and $\mathrm{Co}^{2+}$. Garlic extracts have been reported to contain highly reactive mono to hexa diallyl sulfides and vinyl dithiin isomers (Kimbaris et al., 2006), hence garlic treatment would be expected to have an effect on the metal sorption of $C$. indica. The sorption data were modeled using the Langmuir and Freundlich isotherms and results, including an estimation of biosorption heat, are compared with those reported in the literature.

\section{MATERIALS AND METHODS}

Materials: $C$. indica samples were collected from a local community in Bindura, Zimbabwe were they naturally grow in abundance. The roots were separated and washed thoroughly with running tap water and twice with deionised water. They were then sun dried for 4 weeks before being oven-dried at $65{ }^{\circ} \mathrm{C}$ for $12 \mathrm{~h}$. Dried samples were crushed, ground with a mortar and pestle and sieved (size fraction of $2.5 \mathrm{~mm}$ ).

*Corresponding author: Tel.: +263-2717531/6; fax: +263-7435

E-mail address: courtiema@yahoo.com (C. Mahamadi) 
Acid-treatment: Acid-treatment was necessary to desorb any previously adsorbed metal ions from the biomass, in addition to chemical modification of the sorption sites. Ten grams of dried biomass were placed in $100 \mathrm{~mL}$ of $0.1 \mathrm{M} \mathrm{HNO}_{3}$ solution in a stoppered $250 \mathrm{ml}$ conical flask. The mixture was agitated at $30{ }^{0} \mathrm{C}$ for $12 \mathrm{~h}$ using a water bath shaking at $100 \mathrm{rpm}$. The mixture was then filtered and washed with distilled water until a $\mathrm{pH}$ of 7 was attained before being oven-dried at $65{ }^{\circ} \mathrm{C}$. The acidtreated $C$. indica biomass was designated A-T.

Extraction of Garlic Oil: Garlic oil was extracted by steam distillation using the Soxhlet extraction technique (Dnyaneshwar et al., 2009). Fresh garlic cloves $(50 \mathrm{~g})$ were shelled and thoroughly crushed to a mash using a pistle and mortar. The mash was transferred to the extraction thimble (to fill the thimble 3/4) and extractions were carried out at $58{ }^{0} \mathrm{C}$ using $250 \mathrm{ml}$ of methanol. The extract was evaporated to near dryness using a Rota vapour and the residue was stabilized with $2 \mathrm{ml}$ of ascorbic acid and diluted to $500 \mathrm{ml}$ with deionised water.

Garlic treatment: Five grams of acid-treated $C$. indica were placed in $50 \mathrm{~mL}$ of garlic extract solution in a stoppered $250 \mathrm{ml}$ conical flask. The mixture was agitated at $30{ }^{\circ} \mathrm{C}$ for $12 \mathrm{~h}$ using a water bath shaking at $100 \mathrm{rpm}$. The mixture was then filtered and washed with distilled water before being oven-dried at $65{ }^{0} \mathrm{C}$. The garlic-treated biomass was designated G-T.

Metal solution: Analytical reagent grade chloride salts of $\mathrm{Pb}^{2+}, \mathrm{Co}^{2+}, \mathrm{Cu}^{2+}, \mathrm{Zn}^{2+}$ and $\mathrm{Ni}^{2+}$ were used to prepare stock solutions. Predetermined concentrations of these metal ions were prepared by dilution of the stock solutions using de-ionized water. Real metal concentrations were then determined using a Spectroflame Modula 90/95 Inductively Coupled Argon Plasma Echelle Spectrophotometer (supplied by SPECTRO Analytical Instruments, GmbH, Boschstrabe, Germany).

Sorption dynamics studies: Samples of acid-treated and garlic-treated biomass $(0.25 \mathrm{~g})$ were placed into a series of $250 \mathrm{ml}$ stoppered conical flasks followed by addition of $150 \mathrm{ml}$ of metal solution concentration of $0,25,50,75,100 \mathrm{mg} / \mathrm{l}$. The mixtures were buffered at $\mathrm{pH} 4.85$ using an acetate/acetic acid buffer and the
$\mathrm{pH}$ was adjusted regularly using $0.1 \mathrm{M} \mathrm{NaOH}$ and 0.1 $\mathrm{M} \mathrm{HNO}_{3}$ solutions. The sorption equilibrium data were analyzed using the Langmuir and Freundlich adsorption isotherms.

\section{RESULTS AND DISCUSSION}

Maximum sorption capacity: The classical Langmuir isotherm model was chosen for the estimation of maximum adsorption capacity corresponding to complete monolayer coverage on the biomass surface. The linearised form of the Langmuir model used is shown in Eqn. 1:

$$
\frac{1}{q_{e}}=\frac{1}{\left(q_{\max } b\right) C_{e}}+\frac{1}{q_{\max }}
$$

where $q_{e}$ is the equilibrium metal uptake ( $\left.\mathrm{mg} / \mathrm{g}\right), C_{e}$ is the equilibrium concentration in solution $(\mathrm{mg} / \mathrm{l}), q_{\max }$ represents the maximum adsorption capacity of metal ions, and $b$ is a constant related to the energy or net enthalpy of adsorption through the Arrhenius equation $\left(1 \mathrm{mg}^{-1}\right)$.

The Langmuir isotherm plots for $\mathrm{Pb}^{2+}, \mathrm{Ni}^{2+}, \mathrm{Cu}^{2+}$, $\mathrm{Zn}^{2+}$ and $\mathrm{Co}^{2+}$ are shown in Fig. 1 for the acid-treated biomass and the maximum adsorption capacities for both acid-treated and garlic-treated biomass are shown in Table 1. The results indicate that the $C$. indica biomass had a preferential adsorption capacity for $\mathrm{Pb}^{2+}$ as indicated by its uptake of 30.8 and 37.7 $\mathrm{mg} / \mathrm{g}$ for the acid-treated and garlic-treated biomass respectively, and the biosorption capacity decreased as follows: $\mathrm{Pb}^{2+}>\mathrm{Cu}^{2+}>\mathrm{Zn}^{2+}>\mathrm{Co}^{2+}>\mathrm{Ni}^{2+}$.

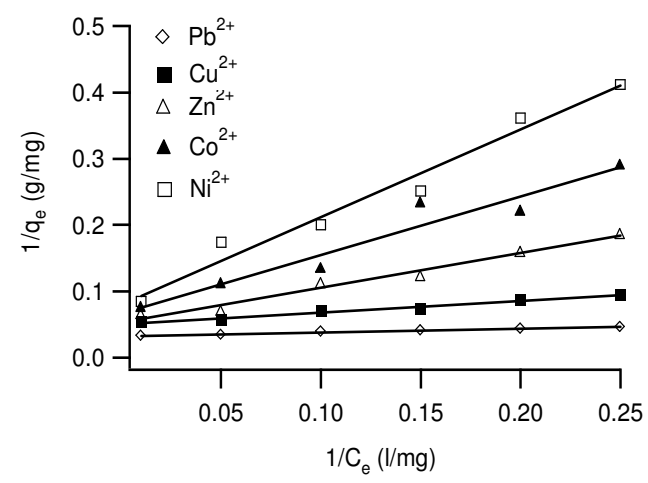

Fig. 1. Langmuir isotherm plots for the uptake of $\mathrm{Pb}^{2+}, \mathrm{Cu}^{2+}, \mathrm{Co}^{2+}$, $\mathrm{Zn}^{2+}$ and $\mathrm{Ni}^{2+}$ by acid-treated $C$. indica (dry weight $=1.7 \mathrm{~g} / \mathrm{l}, \mathrm{pH}=$ 4.85) 
Table 1. Comparison of Langmuir maximum adsorption capacities of acid-treated and garlic-treated C. indica and other biomaterials.

\begin{tabular}{|c|c|c|c|c|c|c|}
\hline \multirow[t]{3}{*}{ Metal ions } & \multicolumn{4}{|c|}{ This study: $C$. indica } & Biomaterials in Literature & \multirow[t]{3}{*}{ References } \\
\hline & \multicolumn{2}{|c|}{ A-T } & \multicolumn{2}{|c|}{ G-T } & & \\
\hline & $\mathrm{q}_{\max }(\mathrm{mg} / \mathrm{g})$ & $\mathrm{R}^{2}$ & $\mathrm{q}_{\max }(\mathrm{mg} / \mathrm{g})$ & $\mathrm{R}^{2}$ & & \\
\hline $\mathrm{Pb}^{2+}$ & 30.8 & 0.98 & 37.7 & 0.97 & $\begin{array}{l}\text { Dried activated sludge (131.6) } \\
\text { Tea waste }(65.0)\end{array}$ & $\begin{array}{l}\text { Wang et al., (2006) } \\
\text { Amarasinghe et al., (2007) }\end{array}$ \\
\hline $\mathrm{Cu}^{2+}$ & 19.4 & 0.98 & 27.9 & 0.99 & $\begin{array}{l}\text { Crab shell particles }(163.9) \\
\text { Spent grain }(10.5)\end{array}$ & $\begin{array}{l}\text { Vijayaraghavan et al., (2006) } \\
\text { Lu and Gibb (2008) }\end{array}$ \\
\hline $\mathrm{Zn}^{2+}$ & 18.8 & 0.98 & 24.7 & 0.95 & $\begin{array}{l}\text { Palm Tree Leaves (14.6) } \\
\text { Caulerpa lentillifera }(2.7)\end{array}$ & $\begin{array}{l}\text { Al-Rub(2006) } \\
\text { Pasavant et al., (2006) }\end{array}$ \\
\hline $\mathrm{Co}^{2+}$ & 15.0 & 0.94 & 20.8 & 0.96 & $\begin{array}{l}\text { Crab shell particles (322.6) } \\
\text { Myriophyllum spicatum } \mathrm{L} \text {. } \\
(2.3)\end{array}$ & $\begin{array}{l}\text { Vijayaraghavan et al., (2006) } \\
\text { Lesage et al., (2007) }\end{array}$ \\
\hline $\mathrm{Ni}^{2+}$ & 14.2 & 0.97 & 21.6 & 0.94 & $\begin{array}{l}\text { Dried activated sludge (238.1) } \\
\text { Baker's yeast }(9.0)\end{array}$ & $\begin{array}{l}\text { Aksu et al., (2002) } \\
\text { Padmavathy (2008) }\end{array}$ \\
\hline
\end{tabular}

Furthermore, the ability of the $C$. indica biomass surface to accommodate each metal ion was evaluated in terms of the maximum specific area of the biomass. The Langmuir adsorption isotherm corresponding to monolayer coverage of the surface $q_{\max }$ is the ultimate sorptive capacity at high concentrations (Febrianto et al., 2009). Therefore, $q_{\max }$ can be used to estimate the specific surface area of the biomass towards the metal ions by Eqn. 2:

$$
S_{a}=\frac{q_{\max } N A}{A W}
$$

where $S_{a}$ is the specific surface area $\left(\mathrm{m}^{2} / \mathrm{g}\right), q_{\max }$ is the monolayer sorption capacity $(\mathrm{mg} / \mathrm{g}), N$ is the Avogadro Number, $A$ is the cross-sectional area of the metal ion $\left(\mathrm{m}^{2}\right)$, and $A W$ is the atomic weight of the metal.

The data in Table 2 indicated that the maximum specific surface area of the biomass surface to accommodate the five metal ions is of the sequence (from the highest to the smallest value): $\mathrm{Pb}^{2+}>\mathrm{Cu}^{2+}=\mathrm{Zn}^{2+}>\mathrm{Co}^{2+}>\mathrm{Ni}^{2+}$, therefore indicating that the sorption capacity increased with increasing maximum specific surface area. The trend in sorption capacity was much similar to the sorption capacity of Staphylococcus saprophyticus BMSZ711 as reported by Zamil et al., (2009), who classified the metal ions as hard, borderline or soft. The biosorption properties of $C$. indica showed that the chemically modified biomass exhibited the highest sorption capacity for the soft ion $\left(\mathrm{Pb}^{2+}\right)$ than borderline $\left(\mathrm{Cu}^{2+}, \mathrm{Zn}^{2+}, \mathrm{Co}^{2+}\right.$, $\mathrm{Ni}^{2+}$ ).
Table 2. Specific surface areas and other ionic size parameters for the removal of the five metal ions by acid-treated $C$. indica biomass $\left(S_{a}=\right.$ specific surface area; $A W=$ atomic weight; $A=$ cross-sectional area of metal ion).

\begin{tabular}{|l|l|l|l|l|}
\hline Metal ions & $q_{\max }(\mathrm{mg} / \mathrm{g})$ & $\begin{array}{l}A \\
\left(\AA^{2}\right)\end{array}$ & $A W(\mathrm{~g} / \mathrm{mol})$ & $S_{a}\left(\mathrm{~m}^{2} / \mathrm{g}\right)$ \\
\hline $\mathrm{Pb}^{2+}$ & 30.8 & 1.18 & 207.2 & 1.31 \\
\hline $\mathrm{Cu}^{2+}$ & 19.4 & 0.73 & 63.5 & 1.03 \\
\hline $\mathrm{Zn}^{2+}$ & 18.8 & 0.75 & 65.4 & 1.03 \\
\hline $\mathrm{Co}^{2+}$ & 15.0 & 0.75 & 58.9 & 0.29 \\
\hline $\mathrm{Ni}^{2+}$ & 14.2 & 0.69 & 58.7 & 0.23 \\
\hline
\end{tabular}

It can be seen that garlic-treatment of $C$. indica enhanced its adsorption capacity for the metal ions under study, e.g., maximum adsorption capacity for $\mathrm{Co}^{2+}$ uptake increased from 15.0 to $20.8 \mathrm{mg} / \mathrm{g}$. The enhancement in adsorption capacity, which can be computed using the ratio $q_{\max , G-T} / q_{\max , A-T}$ varied from 1.22 to 1.52 . It is possible that the highly reactive diallyl sulfides and vinyl dithiin isomers chemically modified the sorption sites and enhanced the uptake capacity. Examples of such active components include monosulfides (e.g., Diallyl sulfide), disulfides (e.g., Allyl methyl disulfide), trisulfides (e.g., Allyl methyl trisulfide), tetrasulfide (Diallyl tetrasulfide) and dithiins (e.g., 2-vinyl-[4H]1.3-dithiin (2-VDT)) (Kimbaris et al., 2006).

Freundlich Isotherm: The Linearised form of the Freundlich isotherm,

$\ln q_{e}=\log K_{F}+\frac{1}{n} \ln C_{e}$

where $K_{F}(\mathrm{mg} / \mathrm{g})(1 / \mathrm{mg})^{\mathrm{n}}$ and $n$ are the Freundlich isotherm parameters, was used. 
The Freundlich isotherm plots for the sorption of $\mathrm{Pb}^{2+}, \mathrm{Ni}^{2+}, \mathrm{Cu}^{2+}, \mathrm{Zn}^{2+}$ and $\mathrm{Co}^{2+}$ are shown in Fig. 2 for the acid-treated biomass and the isotherm parameters for both acid-treated and garlic-treated $C$. indica biomass are shown in Table 3 . The specific capacity (given by the Freundlich $K_{F}$ parameter) show that sorption of $\mathrm{Pb}^{2+}$ by $C$. indica was more favourable $\left(K_{F}=19.6\right.$ and 20.2 for A-T and G-T, respectively) compared to other types of biosorbents (e.g., Tea waste, with $K_{F}=9.65$ ), while the those of $\mathrm{Cu}^{2+}, \mathrm{Zn}^{2+}$ and $\mathrm{Co}^{2+}$ were similar to the literature values. The specific adsorption capacity for $\mathrm{Ni}^{2+}\left(K_{F}\right.$ $=0.06$ and 0.08 for A-T and G-T, respectively), was much lower than values reported in the literature (e.g., Baker's yeast, $K_{F}=3.73$ ). The values of obtained in the study were all greater than unit, indicating that the isotherm was convex and there was strong interaction between the heavy metals. The values also indicate that the sorptive sites were highly heterogeneous.

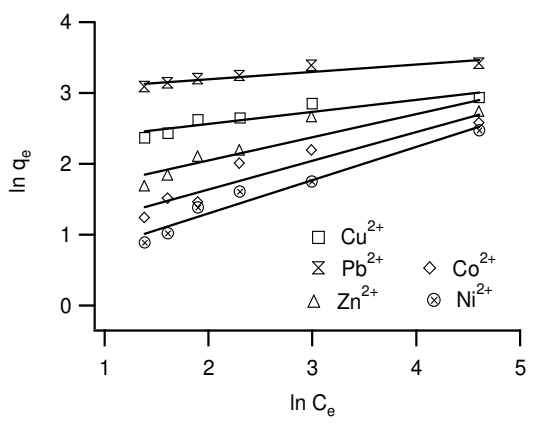

Fig 2. Freundlich isotherm plots for the uptake of $\mathrm{Pb}^{2+}, \mathrm{Cu}^{2+}, \mathrm{Co}^{2+}$, $\mathrm{Zn}^{2+}$ and $\mathrm{Ni}^{2+}$ by acid-treated $C$. indica (dry weight $=1.7 \mathrm{~g} / \mathrm{l}, \mathrm{pH}=$ 4.85)

Table 3. Comparison of Freundlich Isotherm parameters for acid-treated and garlic-treated $C$. indica and other biomaterials $K_{F}$ is in units of $(\mathrm{mg} / \mathrm{g})(1 / \mathrm{mg})^{\mathrm{n}}$.

\begin{tabular}{|c|c|c|c|c|c|c|c|c|}
\hline \multirow{3}{*}{$\begin{array}{l}\text { Metal } \\
\text { ions }\end{array}$} & \multicolumn{6}{|c|}{ This study: $C$. indica } & Biomaterials in the literature & References \\
\hline & \multicolumn{2}{|c|}{$\mathrm{A}-\mathrm{T}$} & \multicolumn{3}{|c|}{ G-T } & \multirow[b]{2}{*}{$R^{2}$} & \multirow{2}{*}{$K_{F} ; n$} & \\
\hline & $K_{F}$ & $n$ & $R^{2}$ & $K_{F}$ & $n$ & & & \\
\hline $\mathrm{Pb}^{2+}$ & 19.6 & 9.73 & 0.86 & 20.2 & 10.2 & 0.84 & $\begin{array}{l}\text { Aspergillus niger }(2.35 ; 2.19) \\
\text { Tea waste }(9.65 ; 2.57)\end{array}$ & $\begin{array}{l}\text { Dursun (2006) } \\
\text { Amarasinghe et al., (2007) }\end{array}$ \\
\hline $\mathrm{Cu}^{2+}$ & 8.69 & 5.81 & 0.84 & 8.93 & 5.92 & 0.82 & $\begin{array}{l}\text { Crab shell particles }(9.13 ; 2.20) \\
\text { Tea waste }(0.70 ; 1.35)\end{array}$ & $\begin{array}{l}\text { Vijayaraghavan et al., (2006) } \\
\text { Amarasinghe et al., (2007) }\end{array}$ \\
\hline $\mathrm{Zn}^{2+}$ & 2.47 & 3.07 & 0.83 & 2.45 & 3.01 & 0.90 & $\begin{array}{l}\text { Palm Tree Leaves }(3.01 ; 3.23) \\
\text { Caulerpa lentillifera }(3.13 ; 1.54)\end{array}$ & $\begin{array}{l}\text { Al-Rub (2006) } \\
\text { Pasavant et al., (2006) }\end{array}$ \\
\hline $\mathrm{Co}^{2+}$ & 0.59 & 2.47 & 0.89 & 0.62 & 2.53 & 0.91 & $\begin{array}{l}\text { Crab shell particles }(1.69 ; 1.41) \\
\text { Myriophyllum spicatum L. }(0.62 ; 2.90)\end{array}$ & $\begin{array}{l}\text { Vijayaraghavan et al., (2006) } \\
\text { Lesage et al., (2007) }\end{array}$ \\
\hline $\mathrm{Ni}^{2+}$ & 0.06 & 2.14 & 0.96 & 0.08 & 2.9 & 0.89 & $\begin{array}{l}\text { Dried activated sludge }(3.80 ; 1.56) \\
\text { Baker's yeast }(3.73 ; 5.88)\end{array}$ & $\begin{array}{l}\text { Aksu et al., (2002) } \\
\text { Padmavathy (2008) }\end{array}$ \\
\hline
\end{tabular}

To further analyze the applicability of the Langmuir parameters in the Freundlich model, we assumed that the interaction between garlic extracts and acidtreated $C$. indica caused an increase in sorptive sites of some specific sorptive energy. The $b$ and $q_{\max }$ values for the gain in sites (GS) can be found by a two parameter search, subject to the constraint that at any given $C_{e}$ value,

$$
q_{e, A-T}+q_{e, G S}=q_{e, G-T}
$$

The values of Langmuir parameters for GS obtained for $\mathrm{Pb}^{2+}$ were $b=0.76 ; q_{\max }=1.5 \mathrm{mg} / \mathrm{g}$. These values were used to generate theoretical best fit plots for the gain in sites (calculated GS) and for the total sorptive sites (calculated G-T). The plots are shown in Figure 3 and the $R^{2}$ values were $0.86,0.86$ and 0.97 for calculated GS, experimental A-T and calculated G-T, respectively. The $R^{2}$ value for experimental G-T show in Table 3 is 0.84 . The improved linearity for the plot for G-T shows that a combination of individual isotherms for (GS and A-T) would result in improved correlation in the Freundlich Isotherm.

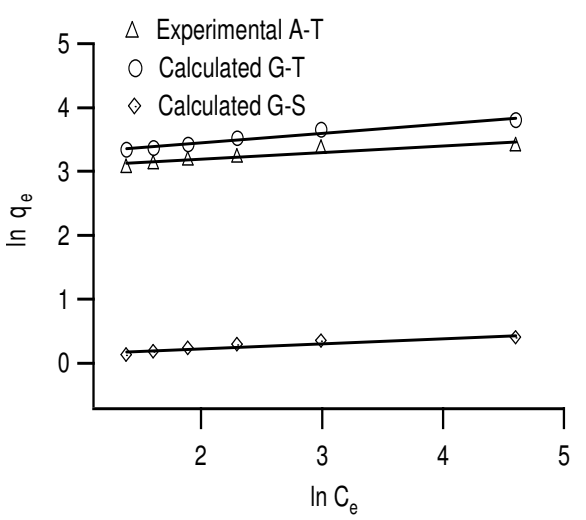

Fig 3. Experimental and theoretical Freundlich isotherm plots for the sorption of $\mathrm{Pb}^{2+}$ by $C$. indica biomass. 
Biosorption heats for $\mathrm{Pb}^{2+}, \mathrm{Ni}^{2+}, \mathrm{Cu}^{2+}, \mathrm{Zn}^{2+}$ and $\mathrm{Co}^{2+}$ : The heat of adsorption $(\Delta H)$ in $\mathrm{kJ} \mathrm{mol}^{-1}$, was evaluated using the integrated Van't Hoff equation, which relates the Langmuir constant, $b$, to the temperature:

$$
b=b_{o} \exp \left[\frac{-\Delta H}{R T}\right]
$$

where $b_{o}$ is a constant containing the entropy term, $R$ a universal gas constant $\left(8.314 \mathrm{JK}^{-1} \mathrm{~mol}^{-1}\right.$ and $T$ is the absolute temperature $(\mathrm{K})$.

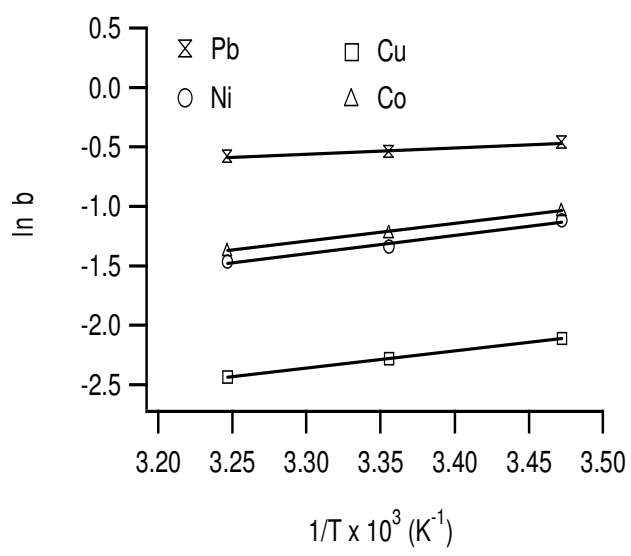

Fig. 4. The determination of biosorption heats for acid-treated Canna indica biomass (dry weight $=1.7$ $\mathrm{g} / \mathrm{l}, \mathrm{pH}=4.85$ ). The plot for $\mathrm{Zn}$ had almost the same slope and intercept as that of Co and is not shown
Fig. 4 shows the plots of $\ln b$ versus $(1 / T)$ and the values of $\Delta H$ obtained are compared with values obtained for other biosorbents in Table 4. The biosorption heats for $\mathrm{Pb}^{2+}, \mathrm{Ni}^{2+}, \mathrm{Cu}^{2+}$, and $\mathrm{Co}^{2+}$ were found to be $-4.438,-7.803,-11.955$ and $-12.716 \mathrm{~kJ}$ $\mathrm{mol}^{-1}$, respectively. These findings also show that $\mathrm{Pb}^{2+}, \mathrm{Ni}^{2+}, \mathrm{Cu}^{2+}$, and $\mathrm{Co}^{2+}$ biosorption processes by $C$. indica are exothermic. The biosorption heats of these metal ions followed the trend: $\mathrm{Ni}^{2+}>\mathrm{Co}^{2+}>\mathrm{Zn}^{2+}>\mathrm{Cu}^{2+}>\mathrm{Pb}^{2+}$. These values are indicative of physisorption and the bonding between the metal ions weakens at higher temperature in contrast with chemical sorption which becomes stronger. Physisorption occurs between the solute and the internal pore surface of the sorbent due to London-van der Waals weak forces (Mazlum et al., 2009). Furthermore, the data in Table 3 reported for other biosorbents show that the values of $\Delta H$ were positive, hence suggesting that the biosorption was endothermic, except for peat $\left(\Delta H=-3.04 \mathrm{~kJ} \mathrm{~mol}^{-1}\right)$, whereas the biosorption of the same metal ions by $C$. indica was exothermic.

Table 4. Values of biosorption heats for acid-treated Canna indica biomass and other biosorbents

\begin{tabular}{|c|c|c|c|c|}
\hline \multirow[t]{2}{*}{ Metal ion } & \multicolumn{2}{|c|}{ This study: $C$. indica } & Biomaterials in the literature & References \\
\hline & $\begin{array}{l}\text { Adsorption } \\
\text { heat }\left(\mathrm{kJ} \mathrm{mol}^{-1}\right)\end{array}$ & $\mathrm{R}^{2}$ & Adsorption heat $\left(\mathrm{kJ} \mathrm{mol}^{-1}\right)$ & \\
\hline $\mathrm{Pb}^{2+}$ & -4.44 & 0.97 & $\begin{array}{l}\text { Aspergilus niger (38.3) } \\
\text { Peat }(-3.04)\end{array}$ & $\begin{array}{l}\text { Dursun }(2006) \\
\text { Ho }(2006)\end{array}$ \\
\hline $\mathrm{Cu}^{2+}$ & -11.96 & 0.99 & $\begin{array}{l}\text { Shells of lentil (15.37) } \\
\text { Aspergilus niger (38.3) }\end{array}$ & $\begin{array}{l}\text { Aydin et al., (2008) } \\
\text { Dursun (2006) }\end{array}$ \\
\hline $\mathrm{Zn}^{2+}$ & -12.51 & 0.98 & Rice bran (23.9) & Wang et al., (2006) \\
\hline $\mathrm{Ni}^{2+}$ & -12.87 & 0.98 & $\begin{array}{l}\text { Tea factory waste (17.07) } \\
\text { Baker's yeast }(30.72)\end{array}$ & $\begin{array}{l}\text { Malkoc and Nuhoglu (2005) } \\
\text { Padmavathy (2008) }\end{array}$ \\
\hline $\mathrm{Co}^{2+}$ & -12.72 & 0.99 & - & \\
\hline
\end{tabular}

Conclusion: The removal of $\mathrm{Cu}^{2+}, \mathrm{Zn}^{2+}, \mathrm{Ni}^{2+}, \mathrm{Pb}^{2+}$ and $\mathrm{Co}^{2+}$ ions by dried roots of $C$. indica biomass was studied in a batch system with respect to initial metal ion concentration and temperature. The Langmuir and Freundlich isotherms were used to model the equilibrium sorption data and it was shown that the metal uptake followed the trend $\mathrm{Pb}^{2+}>\mathrm{Cu}^{2+}>\mathrm{Zn}^{2+}>\mathrm{Co}^{2+}>\mathrm{Ni}^{2+}$. Garlic-treatment of $C$. indica biomass enhanced its sorption capacity for the metal ions and the biosorption process was found to 
be exothermic for all metal ions studied with physisorption being the most likely mechanism of uptake.

Acknowledgements: The authors are grateful to the Trojan Nickel Mine, Bindura for availing their ICP spectrophotometer.

\section{REFERENCES}

Agarwal, GS; Bhuptawat, HK; Chaudhari, S (2006). Biosorption of aqeuous chromium (VI) by Tamarindus indica seeds. Bioresour. Technol. 97, 949-956.

Aksu, Z; Acikel, U; Kabasakal, E; Tezer, S (2002). Equilibrium modeling of individual and simultaneous biosorption of chromium(VI) and nickel(II) onto dried activated sludge. Water. Res., 36, 3063-3073.

Al-Rub, FAA (2006). Biosorption of zinc on palm tree leaves: equilibrium, kinetics, and thermodynamics studies. Separation Sci. and Technol., 41, 3499-3515.

Amarasinghe, BMW; Williams, RA (2007). Tea waste as a low cost adsorbent for the removal of $\mathrm{Cu}$ and $\mathrm{Pb}$ from wastewater. Chem. Eng. J., 132, 299-309.

Das, N; Charumathi, D; Vimala, R (2007). Effect of pretreatment on $\mathrm{Cd}^{2+}$ biosorption by mycelial biomass of Pleurotus florida. African. J. Biotechnol. 6(22), 2555-2558.

Diniz, V; Volesky, B (2005). Effect of counterions on lanthanum biosorption by Sargassum polycystum. Water Res. 39, 2229-2236.

Diniz, V; Weber, ME; Volesky, B; Naja, G (2008). Column biosorption of lanthanum and europium by sargassum. Water Res., 42, 363-371.

Dnyaneshwar, J; Rekha, BN; Parag, RG; Virendra, KR (2009). Extraction of vanillin from vanilla pods: A comparison study of conventional soxhlet and ultrasound assisted extraction. J. Food Eng., 93(4), 421-426.

Dursun, AY (2006). A comparative study on determination of the equilibrium, kinetic and thermodynamic parameters of biosorption of copper(II) and lead(II) ions onto pretreated Aspergillus niger. Biochem. Eng. J., 28, 187195.
Febrianto, J; Kosasih, AN; Sunarso, J; Ju, Y.-H; Indraswati, N; Ismadji, S (2009). Equilibrium and Kinetic studies in adsorption of heavy metals using biosorbent: A summary of recent studied. J. Hazard. Mater., 162, 616-645.

Gupta, S; Babu, BV (2009). Utilization of waste product (tamarind seeds) for the removal of $\mathrm{Cr}(\mathrm{IV})$ from aqueous solutions: Equilibrium, kinetics, and regeneration studies. J. Environ. Manage. 90, 3013-3022.

Hasan, SH; Talat, M; Rai, S (2007). Sorption of cadmium and zinc from aqueous solutions by water hyacinth (Eicchornia crassipes). Bioresour. Technol. 98, 918-928.

Horsfall Jnr, M; Spiff, AI (2005). Effect of 2mercaptoethanoic acid treatment of fluted pumpkin waste (Telfairia occidentalis Hook. F.) on the sorption of $\mathrm{Ni}^{2+}$ ions from aqueous solution. J. Sci. and Industrial Res., 64, 613-620.

Kimbaris, AC; Siatis, NG; Pappas, CS; Tarantilis, PA; Daferera, DJ; Polissiou. MG (2006). Quantitative analysis of garlic (Allium sativum) oil unsaturated acyclic components using FTRaman spectroscopy. Food Chem. 94, 287-295.

Lesage, E; Mundia, C; Rousseau, DPL; Van der Moortel, AMK; Du Laing, G; Meers, E; Tack, FMG; De Pauw, N; Verloo, MG (2007). Sorption of $\mathrm{Co}, \mathrm{Cu}, \mathrm{Ni}$ and $\mathrm{Zn}$ from industrial effluents by the submerged aquatic macrophyte Myriophyllum spicatum L. Ecological Eng., 30, 320-325.

Lesmana, SO; Febriana, N; Soetaredjo, FE; Sunarso, J; Ismadji, S (2009). Studies on potential applications of biomass for the separation of heavy metals from water and wastewater. Biochem. Eng. J., 44, 19-41.

Lu, S; Gibb, SW (2008). Copper removal from wastewater using spent-grain as biosorbent. Bioresour. Technol., 99, 1509-1517.

Mahamadi, C; Nharingo, T (2007). Modeling the kinetics and equilibrium properties of

cadmium biosorption by river green alga and water hyacinth weed. Toxicol. \& Environ. Chem. 89 (2), 297-305.

Mazlum, S; Mazlum, N; Kılıç M; Keskin, ME; Karakaya, H (2009). A critical study on the efficacy of kinetic sorption modeling to elucidate 
the effective removal pathways. Colloids and Surfaces A: Physicochem. Eng. Aspects 337, 185-193.

Naja, G; Volesky, B (2006). Multi-metal biosorption in a fixed-bed flow-through column. Colloids and Surfaces A: Physicochem. Eng. Aspects, 281, 194-201.

Padmavathy, V (2008). Biosorption of nickel(II) ions bay baker's yeast: kinetic, thermodynamic and desorption studies. Bioresour. Technol., 99, 3100-3109.

Pasavant, P; Apiratikul, R; Sungkhum, V; Suthiparinyanont, P; Wattanachira, S; Marhaba, TF (2006). Biosorption of $\mathrm{Cu}^{2+}, \mathrm{Cd}^{2+}, \mathrm{Pb}^{2+}$ and $\mathrm{Zn}^{2+}$ using dried marine green macroalga Caulerpa lentillifera. Bioresour. Technol., 97, 2321-2329.
Vijayaraghavan, K; Palanivelu, K; Velan, M (2006). Biosorption of copper(II) and cobalt(II) from aqueous solutions by crab shell particles. Bioresour. Technol., 97, 1411-1419.

Wang, X; Xia, S; Chen, L; Zhao, J; Chovelon, J; Nicole, J (2006). Biosorption of cadmium(II) and lead(II) ions from aqeuous solutions onto dried activated sludge. J. Environ. Sci., 18, 840-844.

Zamil, SS; Ahmad, S; Choi, MH; Park, JY; Yoon, SC (2009). Correlating metal ionic characteristics with biosorption capacity of Staphylococcus saprohyticus BMSZ711 using QICAR model. Biouresour. Technol. 100, 1895-1902.

Zheng, J.-C; Feng, H.-M; Lam, H.-WM; Lam, K.S.P; Ding, Y.-W; Yu, H.-Q (2009). Removal of $\mathrm{Cu}$ (II) in aqueous media by biosorption using water hyacinth roots as a biosorbent material. J. Hazard.

Mater., 